\title{
A hybrid approach based on artificial neural network and cuckoo algorithm for optimization of the main cutting force during turning of Si brass alloys
}

\author{
Morteza Adineh $^{1}$ [D $\cdot$ Hamid Doostmohammadi ${ }^{1}$
}

Received: 3 August 2020 / Accepted: 23 December 2020 / Published online: 11 January 2021

(c) The Author(s) $2021 \quad$ OPEN

\begin{abstract}
As an innovative approach in this study, artificial neural network and cuckoo algorithm have been applied to estimate and optimize the main cutting forces of various Si brass alloys during turning operation due to economic reasons. Accordingly, the chemical composition ( $\mathrm{Cu}, \mathrm{Zn}$ and $\mathrm{Si}$ contents) and process parameters (cutting speed, feed rate and depth of cut) are simultaneously implemented as input variables and the main cutting force is adjusted as an output variable. Moreover, the genetic algorithm is used to determine the optimum condition of the input parameters to obtain the lowest amounts of the main cutting force. Coupling of the hybrid cuckoo algorithm with artificial neural network has resulted in decreasing the mean absolute percentage error of the optimum structure (6-10-7-1) from 9.025 to $1.59 \mathrm{E}-6 \%$. The validation of the proposed model has been done by performing the new set of experimental tests. The measured and predicted main cutting forces are in good agreement. The Si brass alloys including Zn equivalent about $44.97 \mathrm{wt} \%$ has the lowest main cutting force due to the formation of the Widmanstäetten morphologies in the microstructure. The outcome of this study may be useful for machining industry of the free-cutting Si brasses.
\end{abstract}

Keywords Silicon brass · Artificial neural network · Cuckoo optimization algorithm · Main cutting force

\section{Introduction}

Brass alloys containing of around 2 wt $\%$ lead $(\mathrm{Pb})$ have extensive applications in engineering usages due to their excellent machinability. From one hand, the presence of $\mathrm{Pb}$ encourages the formation of microscopic chip breaker as well as induces the internal lubricant properties to the alloys and from the other hand, due to toxic effect of $\mathrm{Pb}$ restricted the usage of such alloys, significantly. Consequently, proposing of $\mathrm{Pb}$ free brass alloys is hot issue for research and process development [1-3].

Silicon (Si) is one of the most common elements for substitution of $\mathrm{Pb}$ in brass named as $\mathrm{Si}$ brass alloys. $\mathrm{Si}$ is a cheap and abundant element [4] and has significant potential for recycling. The addition of Si to brass can promote the creation of discontinuous chips [5], aid fluidity [6] and improve the strength, wear resistance and dezincification resistance [7].These outstanding characteristics of Si caused to evolve the Si brass alloys as good candidates for substitution of $\mathrm{Pb}$ containing brasses.

Schultheiss et al. [3], by evaluating the machinability of the $\mathrm{Pb}$ containing brass compared to Si alloyed brass, concluded that the cutting forces for Si brass was higher due to the greater yield and tensile strengths and hardness of this alloy. The same result was reported by Nobel et al. [5] however; they found that in comparison to leadless brasses, the machinability based on cutting forces could be improved by addition of Si. Oishi [7] proposed that satisfactory machinability could be obtained by addition of $2-4 \mathrm{wt} \% \mathrm{Si}$. Formation of brittle phases

Morteza Adineh, morteza.adineh@uk.ac.ir | 'Department of Metallurgy and Materials Science, School of Engineering, Shahid Bahonar University of Kerman, Jomhoori Eslami Blvd., Kerman, Iran. 
was reported to be a major cause of the machinability improvement. Adineh et al. [8] represented that not only the presence of brittle phases but also the morphology and hardness of the phases involved had significant role on decreasing the main cutting force of Si brass alloys.

The role of Si on the main cutting force of the turning operation is very important since this parameter has a major role on the energy consumption during the machining process. Therefore, there is a need for formulating and predicting the main cutting force versus the chemical composition of Si brass alloys as well as the machining parameters (including cutting speed (CS), feed rate (FR), and depth of cut (DoC)).

This paper is organized as follows: In Sect. 2, the principle of ANN and COA has been explained. In Sect. 3, the methods of production of samples by casting method, the machining condition and the way of measuring and collecting data have been proposed. In Sect. 4, the results of the ANN simulation, employment of COA to improve the accuracy of the ANN, optimum condition introduced by genetic algorithm and validation of the model by experimental tests are studied. In Sect. 5, we discuss the results of the research as well as the influence of each input parameters on the main cutting force.

\section{Background}

\subsection{Artificial neural network (ANN)}

ANN, i.e., a machine learning technique, uses from past practical data (input values and output values) like human neurons to determine the complex interaction between the practical parameters. ANN learns from inputs and target data in a nonlinear parallel algorithm named feed forward-back propagation [9]. Input layer, one or higher hidden layers, output layer and a lot of nodes are the main components of this algorithm (Fig. 1). Data processing in ANN are carried out in neurons or nodes which are connecting each other by weights $\left(w_{i}\right)$ and bias $(b)$. Every neuron multiplies the input data using its relevant connecting weights and at follows sums the threshold acting as bias. The weight of each parameter is adjusted by considering its significance. Activation function is responsible for summation of the results within each layer and transfer to the next layer neurons [10,11] as following (Eq. 1).

$X_{i}^{(n)}=f\left(\sum_{i} w_{j i}^{(n)} X_{i}^{(n-1)}+b_{j}^{(n)}\right)$

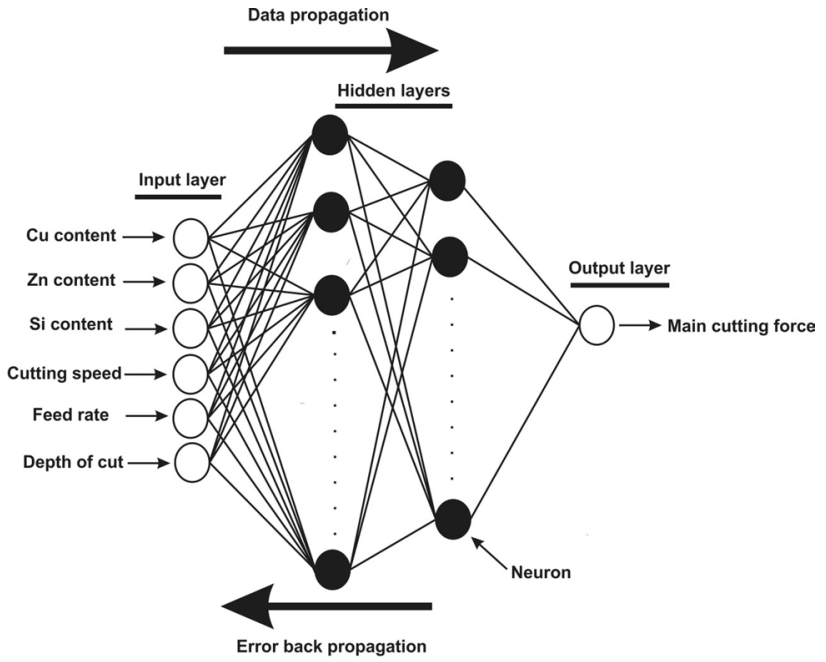

Fig. 1 Typically representation of the ANN components [9]

In which, $X_{i}^{(n)}$ is the neuron $i$ output in $n$th layer, $W_{j i}^{(n)}$ is defined as the weight of neuron $i$ in $(n-1)$ th layer to $j$ in the $n$th layer and $b_{j}^{(n)}$ is considered as the bias of neuron $j$ in the $n$th layer [12].

There are various activation functions for connecting of the ANN components including Tansig, Logsig and Pureline as shown in Eqs. 2-4.

$\operatorname{Tansig}(\mathrm{x})=(\exp (\mathrm{x})-\exp (-\mathrm{x})) /(\exp (\mathrm{x})+\exp (-\mathrm{x}))$

$\operatorname{Logsig}(x)=1 /(1+\exp (-x))$

Pureline $(x)=x$

Generally, a backward propagation (BP) strategy employs for training of proposed feed forward networks [13]. This strategy estimates the weights at the start of the process in a random way. Then, the estimated output compares to the datum and the error sends back to the initial layer. By consideration of the error as a criterion, the weights are adjusted to minimize the error [9].

ANNs have attracted extensive attention in various aspects of casting and machining sciences for optimization and predicting of materials properties as well as materials behavior by excellent precision. Manjunath Patel et al. [14] utilized BP algorithm tuned neural network for modeling of squeeze casting process. The input data were pressure duration, squeeze pressure and pouring and die temperatures. Surface roughness and tensile strength were adopted as the output data. The results showed the capability of the model to make precise prediction. The combined method of genetic algorithm (GA) and BP neural network was also used effectively in mold 
breakout prediction in slab continuous casting by $\mathrm{He}$ and Zhang [15]. Arafat et al. [16] could model the energy consumption and surface roughness of the bovine horns versus process parameters of the face milling with high accuracy prediction by using ANN. Considering the significance and complexity of the casting and machining of the brass, it is necessary to employ the advanced techniques for comprehensive analysis as well as determination of the optimum condition for minimization of the main cutting force during the turning of Si brass alloys.

\subsection{Cuckoo optimization algorithm (COA)}

COA, i.e., a powerful strategy for simulation of non-linear issues, is inspired from specific breeding and egg laying of typical cuckoo species. Female types of cuckoos put their eggs in the nest of some chosen host birds due to the similarity between the colours and patterns of those species. After hatching the egg, the cuckoo chicks throw out the eggs and chicks of the host bird. Usually, $10 \%$ of the host birds distinguish the presence of strange eggs and throw them out of the nest. The suitability of the area for survival of the cuckoos is determined by the rate of the raised eggs. The surviving chicks of the cuckoo instinctly repeat the same trend at future $[17,18]$. When the surviving chicks become a mature, they start to form communities which have their own habitat to live. It is necessary to note that the most appropriate region is determined as a distinction of cuckoos for migration. In this algorithm, each egg in the nest and a cuckoo egg are representatives for a not-so-good solution and a new potentially better solution, respectively $[17,18]$. The convergence takes place to a state that just one cuckoo society remains [19]. The employment of COA as hybrid approach by ANN is considered as advanced technique for simulation of lot of engineering process [19-21].

The COA has been implemented for estimating the crack depth and location in cantilever Euler-Bernoulli beams by Moezi et al. [20]. It is also used for simultaneous optimization of maximum material removal rate and minimum surface roughness during electro chemical machining process [21]. The results of confirmatory experiments verified the suitability of this method. COA was successfully implemented for optimization of the production time in the multi-pass milling process and hybridization of this approach was encouraged for further improvement [22]. The ANN-COA flowchart is represented schematically in Fig. 2.

To the best of our knowledge, optimization and determination of the influence of effective parameters on brass goods alloys preparation by casting, i.e., $\mathrm{Cu}(\mathrm{wt} \%), \mathrm{Zn}$ (wt\%) and $\mathrm{Si}(\mathrm{wt} \%)$, cutting speed (CS), feed rate (FR) and depth of cut $(\mathrm{DoC})$ on the main cutting force of turning

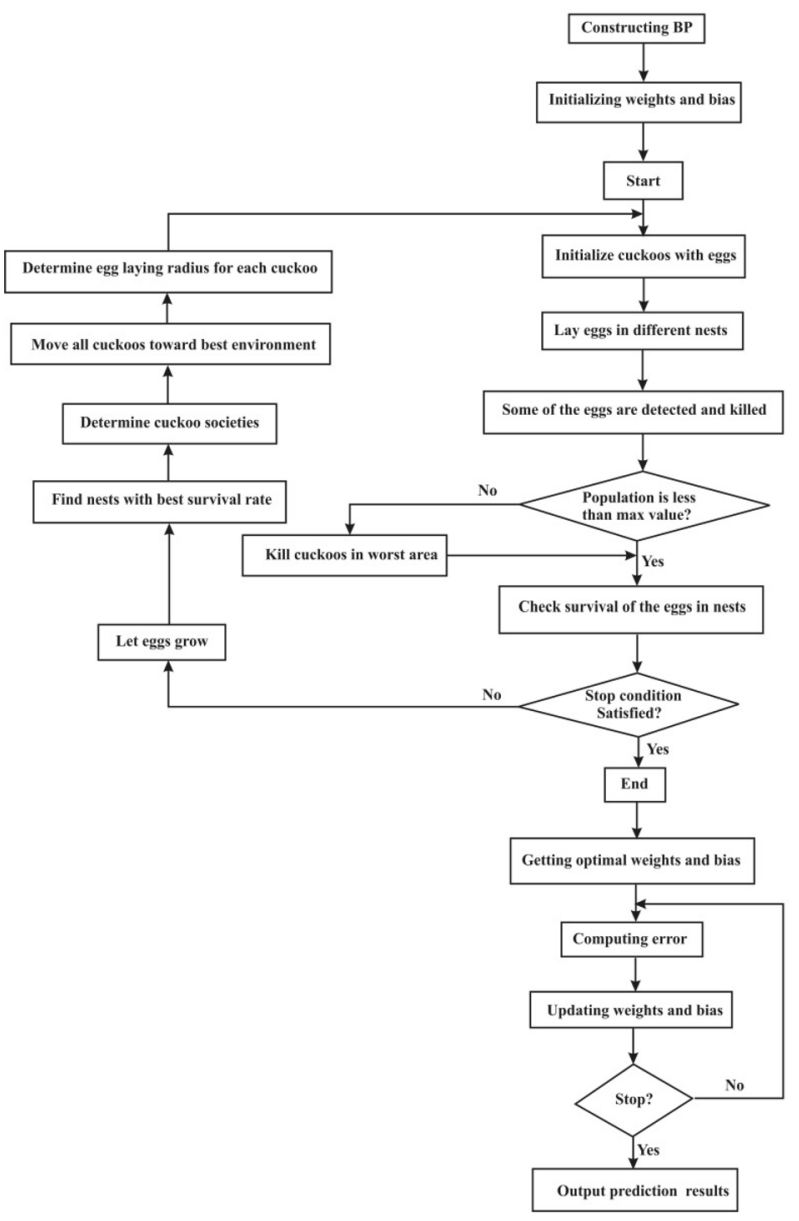

Fig. 2 The schematic representation of the ANN-COA flowchart $[20,23]$

operation have not been investigated, yet. Accordingly, as an innovative approach in this study, a hybrid ANN-COA strategy is employed for modeling and optimization of the main cutting force during the turning of Si brass alloys by simultaneous implementation of chemical composition and process parameters as inputs variables. In this study, the COA algorithm was implemented in order to optimize the weight and bias of the optimum network structure obtained by ANN.

The main contribution of the proposed model are: (1) The feasibility of the study of ANN, ANN-COA and ANN-COA-GA simulation in modeling of machining behavior by consideration of the most effecting practical parameters, (2) Comparison of ANN, ANN-COA models with each other, (3) Investigating the effect of $\mathrm{Cu}, \mathrm{Zn}$ and Si contents, CS, FR and DoC on the main cutting force, (4) Integrating the best model with GA simulation to optimize the main cutting force, (5) Verifying the predicted optimum value. 
Fig. 3 The brief methodology used for simulating of the main cutting force

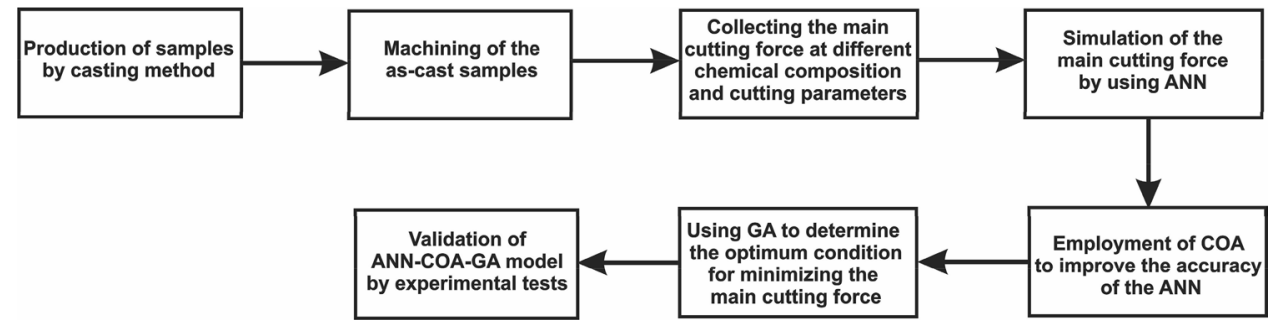

Table 1 Chemical composition of the various Si brass alloys casted in present study

\begin{tabular}{lllll}
\hline Sample no. & Cu (wt\%) & Zn (wt\%) & Si (wt\%) & $\begin{array}{l}\text { Zinc } \\
\text { equivalent } \\
\text { (wt\%) }\end{array}$ \\
\hline 1 & 65.48 & 34.52 & 0.00 & 34.52 \\
2 & 66.17 & 33.00 & 0.83 & 38.40 \\
3 & 65.06 & 33.07 & 1.87 & 44.30 \\
4 & 64.78 & 32.94 & 2.28 & 46.20 \\
5 & 64.42 & 31.96 & 3.62 & 51.40 \\
6 & 70.42 & 29.58 & 0.00 & 29.58 \\
7 & 70.18 & 29.05 & 0.77 & 34.37 \\
8 & 68.88 & 29.94 & 1.18 & 37.73 \\
9 & 68.83 & 29.21 & 1.96 & 41.49 \\
10 & 69.19 & 27.33 & 3.48 & 47.30 \\
\hline
\end{tabular}

\section{Experimental procedures}

The methodology of this study is briefly shown in Fig. 3 . Preparations of cast samples were done by adding different amounts of high purity Si to $\mathrm{Cu}_{65} Z_{35}$ and $\mathrm{Cu}_{70} \mathrm{Zn}_{30}$ base brasses. The melting process was performed in an electric furnace and then the melts were poured in the cylindrical sand moulds with the height and diameter of 200 and $30 \mathrm{~mm}$. The chemical composition of the Si brass alloys were determined by mass spectroscopy analysis and shown in Table 1.

The main cutting force was measured by a piezoelectric dynamometer KISTLER 9257B. The tests were done using DNMG 150608-PM inserts with the grade of YBC351 (indexed based on ISO 1832) under the dry conditions and the rake angle of $0^{\circ}$. To enhance the accuracy of the analysis, the main cutting force of every cutting condition was measured three times and the average values were used as input during the training and testing networks.

In this study, the content of $\mathrm{Cu}, \mathrm{Zn}$ and $\mathrm{Si}$ as well as the CS, FR and DoC were considered as the input variables while; the main cutting force was selected as output variable. The ranges of the input parameters were selected based on the results obtained in literatures [8,
Table 2 Statistical information of the dataset

\begin{tabular}{|c|c|c|c|c|}
\hline Parameters & Maximum & Minimum & Average & $\begin{array}{l}\text { Standard } \\
\text { deviation }\end{array}$ \\
\hline \multicolumn{5}{|l|}{ Input variable } \\
\hline Cu content (wt\%) & 70.42 & 64.42 & 67.34 & 2.28 \\
\hline Zn content (wt\%) & 34.52 & 27.33 & 31.05 & 2.21 \\
\hline Si content (wt\%) & 3.62 & 0 & 1.60 & 1.24 \\
\hline $\begin{array}{l}\text { Cutting speed } \\
\left(\mathrm{m} \mathrm{min}^{-1}\right)\end{array}$ & 94.2 & 33.4 & 81.48 & 21.14 \\
\hline Feed rate $\left(\mathrm{mm} \mathrm{rev}^{-1}\right)$ & 0.2 & 0.08 & 0.12 & 0.03 \\
\hline Depth of cut (mm) & 1 & 0.25 & 0.53 & 0.16 \\
\hline \multicolumn{5}{|l|}{ Output variable } \\
\hline $\begin{array}{l}\text { Main cutting force } \\
\text { (N) }\end{array}$ & 157 & 40 & 86.45 & 0.16 \\
\hline
\end{tabular}

24]. From 92 repeatable experimental data sets, 69 tests were selected for training and 23 for testing the network in a random way. Table 2 abbreviates the statistical information of experimental data. All data must be normalized in the range of [0.1-1] using Eq. 5.

$X_{\text {norm }}=0.8\left(\frac{\left(X-X_{\min }\right)}{\left(X_{\max }-X_{\min }\right)}\right)+0.1$

In which, $X_{\max }$ and $X_{\min }$ are maximum and minimum values of the variable $X$ [12].

Levenberg-Marquardt (LM) strategy on the basis of multilayer feed forward back propagation was employed for the determination of weights and biases during the training of the network. The ANN simulation was carried out by Toolbox of Matlab V7.12. Evaluations of various networks were carried out by consideration of mean absolute percentage error (MAPE) as criteria (Eq. 6). The best ANN architecture was determined as the structure with the lower MAPE.

MAPE $=\frac{1}{L}\left[\sum_{T=1}^{L} \frac{(/ \mathrm{d}(\mathrm{t})-\mathrm{p}(\mathrm{t}) /)}{\mathrm{d}(\mathrm{t})}\right] \times 100$ 
In which, $L$ indicates the test data number, $d(t)$ and $p(t)$ are real and model prediction values, respectively [12].

Tansig, logsig and pureline were tested for activation functions of hidden layer in different ANN structures. For all ANN structures, the pureline was used as an activation function of the output layer.

Table 3 abbreviates the preset parameters of the COA algorithm for optimization of the weight and bias of the optimum network structures.

The sensitivity tests were carried out for optimized network of ANN-COA to investigate the relative importance of each input parameters. In this method, constant rates of variation $(+5,-5,+10$ and -10$)$ were chosen for every input data one at a time to calculate the change in outputs by Eq. 7.

Table 3 Preset parameters of the COA strategy used in this work

\begin{tabular}{lc}
\hline Property & Value \\
\hline Number of initial population & 150 \\
Maximum number of cuckoo & 50 \\
Maximum number of eggs & 9 \\
Minimum number of eggs & 2 \\
Control parameter of egg laying & 1 \\
Knn cluster number & 2 \\
\hline
\end{tabular}

$\mathrm{S}_{\mathrm{i}}(\%)=1 / \mathrm{N} \sum_{\mathrm{j}=1}^{\mathrm{N}}(\% \text { change in output } / \% \text { change in input })_{\mathrm{j}} * 100$

In this equation, $S_{i}(\%)$ and $N$ are the sensitivity level and the number of data which were employed for testing the network.

LEICA DMLM light optical microscope and X-ray diffraction (XRD, Xpert) was utilized for phase characterization. The Brinell hardness method was used under the load of $62.5 \mathrm{kN}$ for $60 \mathrm{~s}$ to compare the hardness of samples.

\section{Results}

Figure 4 depicts the dataset box plot for the inputs data. As shown, the median of Cu content, Zn content, CS, FR and DoC are in the box center showing that the distributions of these input data are symmetric. While, the median of the Si content skews to the lower amounts indicating that the values of the lower Si contents are closer together than the higher values. Also, there are not any outliers data for all variables.

Over than 100 ANN architectures were studied to determine the best structure including the higher regression as well as lower MAPE. Table 4, typically represents the
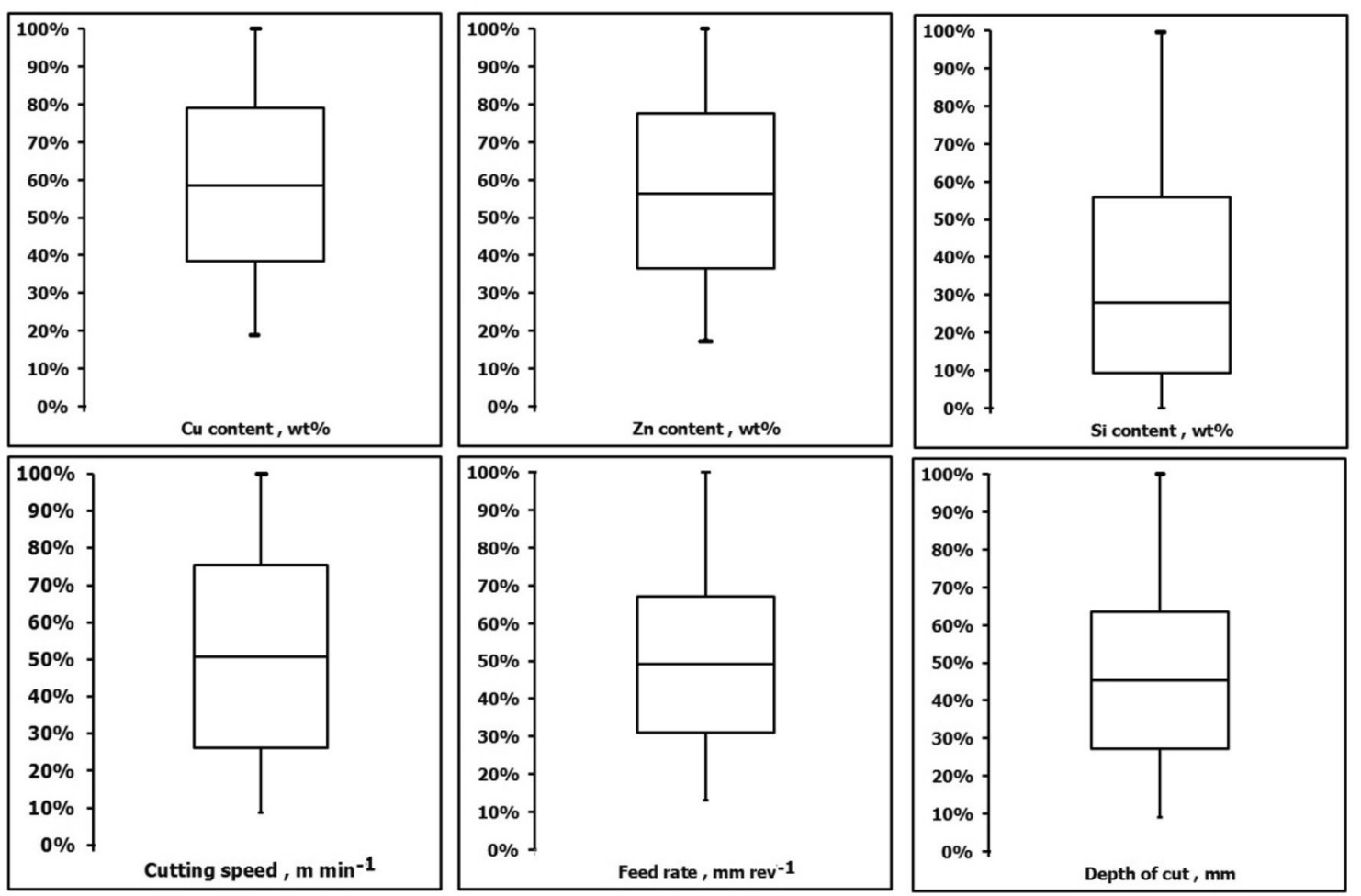

Fig. 4 The description of inputs dataset in box plot 
Table 4 Typically representation of ANN architectures with acceptable performances

\begin{tabular}{|c|c|c|}
\hline Network number & ANN structure & Activation function \\
\hline 0 & 3 & logsig \\
\hline 1 & 3 & tansig \\
\hline 2 & 5 & logsig \\
\hline 3 & 5 & tansig \\
\hline 4 & 7 & logsig \\
\hline 5 & 7 & tansig \\
\hline 6 & 3,5 & logsig, logsig \\
\hline 7 & 3,5 & tansig, tansig \\
\hline 8 & 5,5 & logsig, logsig \\
\hline 9 & 5,5 & $\operatorname{tansig,~tansig~}$ \\
\hline 10 & 7,5 & logsig, logsig \\
\hline 11 & 7,5 & tansig, tansig \\
\hline 12 & 10,5 & logsig, logsig \\
\hline 13 & 10,5 & tansig, tansig \\
\hline 14 & 15,5 & logsig, logsig \\
\hline 15 & 15,5 & tansig, tansig \\
\hline 16 & 3,3 & logsig, logsig \\
\hline 17 & 3,3 & tansig, tansig \\
\hline 18 & 5,3 & logsig, logsig \\
\hline 19 & 5,3 & tansig, tansig \\
\hline 20 & 7,3 & logsig, logsig \\
\hline 21 & 7,3 & tansig, tansig \\
\hline 22 & 10,3 & logsig, logsig \\
\hline 23 & 10,3 & tansig, tansig \\
\hline 24 & 15,3 & logsig, logsig \\
\hline 25 & 15,3 & tansig, tansig \\
\hline 26 & 3,7 & logsig, logsig \\
\hline 27 & 3,7 & tansig, tansig \\
\hline 28 & 5,7 & logsig, logsig \\
\hline 29 & 5,7 & tansig, tansig \\
\hline 30 & 7,7 & logsig, logsig \\
\hline 31 & 7,7 & tansig, tansig \\
\hline 32 & 10,7 & logsig, logsig \\
\hline 33 & 10,7 & tansig, tansig \\
\hline 34 & 15,7 & logsig, logsig \\
\hline 35 & 15,7 & tansig, tansig \\
\hline
\end{tabular}

characteristics of some of these networks with acceptable performance. Figure 5 compares the MAPE and regression of these structures. The entire designed networks had six input neurons and one output neuron. The network number 33 with 6-10-7-1 structure and activation functions tansig between the hidden layers showed the best ability

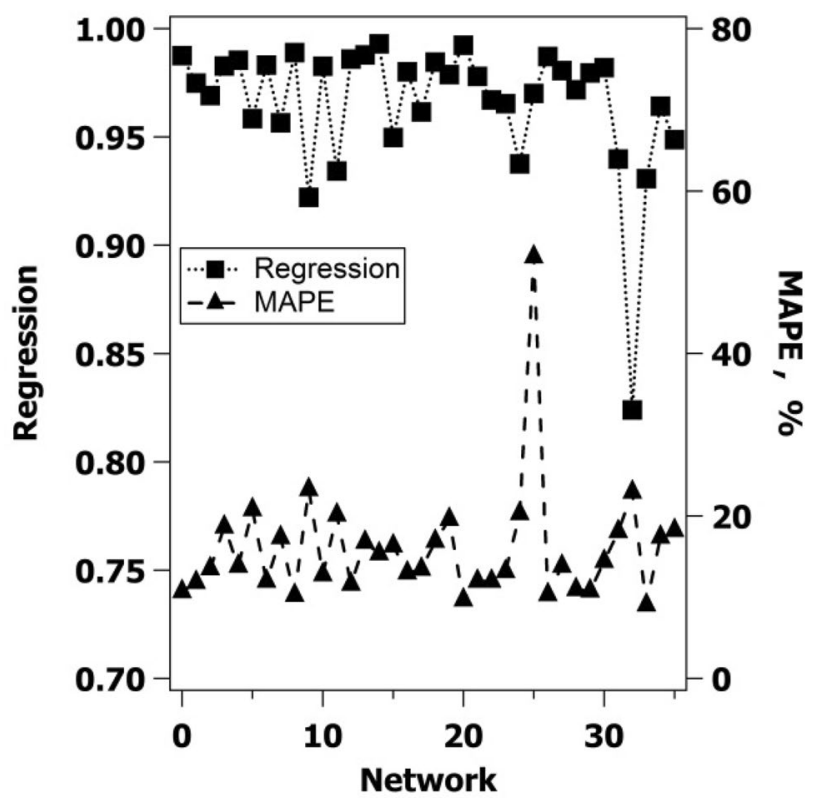

Fig. 5 Typically comparison of regression and MAPE for the most appropriate networks

to predict the data. Accordingly, network 33 had relatively high MAPE about $9.025 \%$ during testing step. Moreover, the MAEP during the training step changed between $3.759 \%$ and 5.075 .

To enhance the accuracy of ANN proposed network, a hybrid ANN-COA strategy was employed. This approach caused the MAPE of the ANN network to decrease from 9.025 to $1.59 \mathrm{E}-6 \%$. The MAPE of the ANN-COA network changed between $1.52 \mathrm{E}-8$ and $1.37 \mathrm{E}-10$ during the training step. The results of a regression analysis between the experimental and ANN-COA predicted data are indicated in Fig. 6. Accordingly, ANN-COA could improve the regression from 0.9942 to 0.999 for training data and 0.9307 to 0.999 for testing data. These results indicated the outstanding prediction capability of the ANN-COA in present work. The ANN has shown a good capability for predicting the main cutting force versus process parameters in Ref. [16]. However; the results of this study indicated that for predicting the main cutting force versus both process parameters and chemical composition, the hybrid ANN-COA should be used.

The experimental and predicted results of the main cutting force as well as the calculated errors for training and testing data are presented in Tables 5 and 6, respectively. 
Fig. 6 Regression analysis of ANN-COA for main cutting force $\mathbf{a}$ training data $\mathbf{b}$ testing data

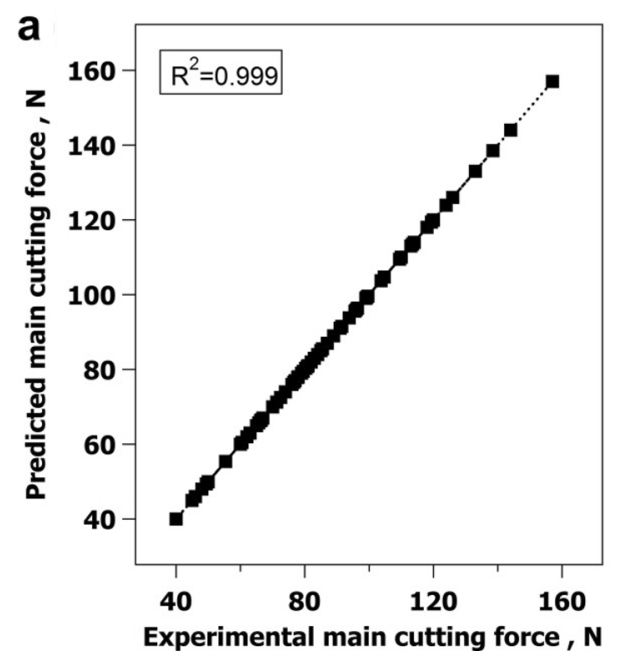

The results of the sensitivity analysis for the main cutting force versus input variables are shown in Fig. 7. Negative values represent that the main cutting force decrease with increasing of the value of the input variable and vice verca. According to Fig. 7, by consideration of the operational parameters, $\mathrm{FR}$ and $\mathrm{DoC}$ with positive effect are the main effective parameters while, by consideration of the chemical composition, Si content of the alloy by negative effect is the most effective parameter on the main cutting force.

To explain the results of sensitivity analysis, optical microscope and XRD analysis were employed. Typically, Figs. 8 and 9 show the optical microscope images and XRD spectra of samples 6, 9 and 10, respectively. As shown in Figs. 8a and 9a, the base alloy was composed of large grains of $a$ phase, i.e., a solid solution with FCC structure $[25,26]$. As shown in Figs. $8 b$ and $9 b$, the addition of Si (1.96 wt\%) to the base alloy (sample 9), encouraged the formation of brittle intermetallic phase including $\beta^{\prime}(\mathrm{CuZn})[24,25]$. The presence of higher $\mathrm{Si}$ content (3.48 wt\%) facilitated the formation of another intermetallic compound $\left(\mathrm{Cu}_{5} \mathrm{Zn}_{8}\right)$ [24] beside the $\beta^{\prime}$ phase (Figs. 8c, 9c).

The effect of $\mathrm{Si}$ content on the average diameter of the grains (ADG) and brinell hardness of the $\mathrm{Cu}_{70} \mathrm{Zn}_{30}$ base brass are shown in Figs. 10 and 11, respectively. Figure 10 confirmed that the presence of Si up to $3.48 \mathrm{wt} \%$ decreased the ADG of the base alloy from 300 to $11 \mu \mathrm{m}$. While, the same changes in Si content increased the hardness of the base brass from 35 to $218 \mathrm{HB}$ (Fig. 11). In summary, higher Si content of the $\mathrm{Cu}_{70} \mathrm{Zn}_{30}$ base brass from one hand encouraged the formation of finer grains and from the other hand facilitated the formation of brittle intermetallic compounds, i.e., $\beta^{\prime}$ and [8]. Accordingly, Si content had notable effect on the mechanical behavior and microstructure of the base brass.

Genetic algorithm (GA) was used to determine the optimum condition of the input parameters for obtaining the minimum amounts of the main cutting force by using the ANN-COA model. According to the results of GA, combination of input variable as $\mathrm{Cu}=68.5 \mathrm{wt} \%, \mathrm{Zn}=28.78 \mathrm{wt} \%$, $\mathrm{Si}=2.72 \mathrm{wt} \%, \mathrm{CS}=86.78 \mathrm{~m} \mathrm{~min}^{-1}, \mathrm{FR}=0.18 \mathrm{~mm} \mathrm{rev}^{-1}$ and $\mathrm{DoC}=0.66 \mathrm{~mm}$ enable the main cutting force to decrease as minimum as possible. Validation of the proposed optimum condition was carried out by introducing of various practical parameters to optimum ANN-COA-GA model and estimating the related error as shown in Table 7.

The zinc equivalent (ZE) factor is defined as Eq. 8. According to this equation, each alloying element has the coefficient with the effect similar to the addition of $\mathrm{Zn}$. This method offered the coefficient of 10 for Si [27].

$Z E=\frac{\left[\% Z n+\sum(\% M \times \text { coeff })\right] 100}{\left.\left[\% Z n+\sum(\% M \times \text { coeff })\right]+\% C u\right]}$

It was observed that the optimum proposed alloy by ANN-COA-GA model had the ZE equal to $44.97 \mathrm{wt} \%$. This value was between the $Z E$ of sample 3 ( $44.3 \mathrm{wt} \%$ ) and sample 4 (46.2 wt\%). Figure 12 typically shows the optical micrograph of samples 3 and 4 . As shown, the $a$ phase is distributed in continuous matrix of $\beta^{\prime}$ phase. Moreover, Fig. 12c confirmed the presence of Widmanstäetten plates and needles geometry of the $a$ phase.

The XRD patterns of the as cast and chip of the sample 3 at $\mathrm{CS}=94.2 \mathrm{~m} \mathrm{~min}^{-1}, \mathrm{FR}=0.11 \mathrm{~mm} \mathrm{rev}^{-1}$ and $\mathrm{DoC}=1 \mathrm{~mm}$ is shown in Fig. 13. Compared to as cast sample, the XRD peaks of the chip became broad and shifted to the lower 2Ө. This behavior was also observed in Ref. [28]. 
Table 5 Experimental data and predicted output from the ANN-COA network for training set

\begin{tabular}{|c|c|c|c|c|c|c|c|c|c|}
\hline \multirow[t]{2}{*}{ No. } & \multirow{2}{*}{$\begin{array}{l}\text { Cu content } \\
\text { (wt\%) }\end{array}$} & \multirow{2}{*}{$\begin{array}{l}\text { Zn content } \\
\text { (wt\%) }\end{array}$} & \multirow{2}{*}{$\begin{array}{l}\text { Si content } \\
\text { (wt } \%)\end{array}$} & \multirow{2}{*}{$\begin{array}{l}\text { Cutting speed } \\
\left(\mathrm{m} \mathrm{min}^{-1}\right)\end{array}$} & \multirow{2}{*}{$\begin{array}{l}\text { Feed rate } \\
\left(\mathrm{mm} \mathrm{rev}^{-1}\right)\end{array}$} & \multirow{2}{*}{$\begin{array}{l}\text { Depth of } \\
\text { cut (mm) }\end{array}$} & \multicolumn{3}{|c|}{ Main cutting force $(\mathrm{N})$} \\
\hline & & & & & & & Measured & Predicted & Error \\
\hline 1 & 64.78 & 32.94 & 2.28 & 94.2 & 0.14 & 0.5 & 85 & 84.9999999998867 & $3.29 \mathrm{E}-11$ \\
\hline 2 & 64.42 & 31.96 & 3.62 & 94.2 & 0.11 & 0.5 & 91 & 91.0000000000484 & $2.81 \mathrm{E}-11$ \\
\hline 3 & 65.06 & 33.07 & 1.87 & 94.2 & 0.11 & 0.5 & 63 & 63.0000000001322 & 4.17E-10 \\
\hline 4 & 64.78 & 32.94 & 2.28 & 94.2 & 0.11 & 0.25 & 45 & 45.0000000000944 & $2.68 \mathrm{E}-10$ \\
\hline 5 & 69.19 & 27.33 & 3.48 & 94.2 & 0.11 & 1 & 133 & 133.000000000012 & $4.02 \mathrm{E}-11$ \\
\hline 6 & 69.19 & 27.33 & 3.48 & 94.2 & 0.11 & 0.75 & 113.5 & 113.500000000024 & $1.84 \mathrm{E}-11$ \\
\hline 7 & 64.78 & 32.94 & 2.28 & 94.2 & 0.11 & 0.75 & 96 & 95.9999999999813 & $7.69 \mathrm{E}-11$ \\
\hline 8 & 65.48 & 34.52 & 0 & 94.2 & 0.14 & 0.5 & 99.6 & 99.6000000000305 & 4.17E-11 \\
\hline 9 & 70.42 & 29.58 & 0 & 94.2 & 0.11 & 0.75 & 110 & 110.000000000039 & $1.42 \mathrm{E}-11$ \\
\hline 10 & 65.48 & 34.52 & 0 & 66.8 & 0.11 & 0.5 & 87 & 87.0000000000362 & $1.17 \mathrm{E}-10$ \\
\hline 11 & 68.88 & 29.94 & 1.18 & 94.2 & 0.11 & 0.5 & 76.6 & 76.6000000000446 & $5.53 \mathrm{E}-11$ \\
\hline 12 & 66.17 & 33 & 0.83 & 94.2 & 0.2 & 0.5 & 118 & 118.000000000025 & $8.54 \mathrm{E}-11$ \\
\hline 13 & 68.88 & 29.94 & 1.18 & 94.2 & 0.08 & 0.5 & 66.5 & 66.4999999999947 & $1.89 \mathrm{E}-10$ \\
\hline 14 & 66.17 & 33 & 0.83 & 47.1 & 0.11 & 0.5 & 87 & 87.0000000000785 & $9.8 \mathrm{E}-11$ \\
\hline 15 & 70.42 & 29.58 & 0 & 94.2 & 0.11 & 0.25 & 46 & 46.0000000000288 & $5.99 \mathrm{E}-10$ \\
\hline 16 & 64.78 & 32.94 & 2.28 & 94.2 & 0.11 & 0.5 & 67 & 66.999999999943 & $4.03 E-10$ \\
\hline 17 & 64.42 & 31.96 & 3.62 & 94.2 & 0.11 & 0.75 & 126 & 126.00000000001 & $3.26 \mathrm{E}-11$ \\
\hline 18 & 68.83 & 29.21 & 1.96 & 66.8 & 0.11 & 0.5 & 81 & 81.0000000000551 & $7.33 \mathrm{E}-11$ \\
\hline 19 & 70.18 & 29.05 & 0.77 & 94.2 & 0.11 & 0.5 & 77 & 77.0000000000845 & $2.55 \mathrm{E}-11$ \\
\hline 20 & 68.88 & 29.94 & 1.18 & 94.2 & 0.11 & 1 & 138.5 & 138.500000000006 & $2.05 \mathrm{E}-11$ \\
\hline 21 & 68.83 & 29.21 & 1.96 & 94.2 & 0.11 & 0.5 & 79.5 & 79.5000000000181 & $1.12 \mathrm{E}-10$ \\
\hline 22 & 68.88 & 29.94 & 1.18 & 94.2 & 0.11 & 0.25 & 46 & 46.0000000000431 & $2.13 \mathrm{E}-10$ \\
\hline 23 & 70.18 & 29.05 & 0.77 & 94.2 & 0.14 & 0.5 & 99.3 & 99.2999999999613 & $3.72 \mathrm{E}-11$ \\
\hline 24 & 68.88 & 29.94 & 1.18 & 94.2 & 0.14 & 0.5 & 89 & 89.0000000000259 & $5.3 \mathrm{E}-11$ \\
\hline 25 & 70.42 & 29.58 & 0 & 94.2 & 0.08 & 0.5 & 65.7 & 65.7000000001113 & $1.14 \mathrm{E}-10$ \\
\hline 26 & 64.78 & 32.94 & 2.28 & 94.2 & 0.2 & 0.5 & 109.5 & 109.500000000039 & $1.83 \mathrm{E}-11$ \\
\hline 27 & 65.48 & 34.52 & 0 & 94.2 & 0.2 & 0.5 & 119.4 & 119.399999999927 & $5.71 \mathrm{E}-10$ \\
\hline 28 & 69.19 & 27.33 & 3.48 & 94.2 & 0.11 & 0.5 & 78 & 78.0000000000419 & $7.4 \mathrm{E}-11$ \\
\hline 29 & 64.42 & 31.96 & 3.62 & 47.1 & 0.11 & 0.5 & 79 & 79.0000000000979 & $3.01 \mathrm{E}-10$ \\
\hline 30 & 70.18 & 29.05 & 0.77 & 47.1 & 0.11 & 0.5 & 85.5 & 85.5000000000699 & $1.11 \mathrm{E}-10$ \\
\hline 31 & 68.83 & 29.21 & 1.96 & 47.1 & 0.11 & 0.5 & 78 & 78.0000000000595 & $3.15 \mathrm{E}-10$ \\
\hline 32 & 68.83 & 29.21 & 1.96 & 94.2 & 0.2 & 0.5 & 113 & 113.000000000017 & $2.86 \mathrm{E}-11$ \\
\hline 33 & 69.19 & 27.33 & 3.48 & 94.2 & 0.2 & 0.5 & 120 & 120.000000000011 & $5.33 \mathrm{E}-11$ \\
\hline 34 & 64.42 & 31.96 & 3.62 & 94.2 & 0.14 & 0.5 & 103.7 & 103.700000000062 & $3.6 \mathrm{E}-11$ \\
\hline 35 & 64.78 & 32.94 & 2.28 & 47.1 & 0.11 & 0.5 & 67 & 66.9999999999897 & $2.22 \mathrm{E}-10$ \\
\hline 36 & 66.17 & 33 & 0.83 & 94.2 & 0.11 & 0.25 & 50 & 50.0000000000639 & $1.42 \mathrm{E}-10$ \\
\hline 37 & 64.42 & 31.96 & 3.62 & 94.2 & 0.08 & 0.5 & 83 & 83.0000000000592 & $2.78 \mathrm{E}-11$ \\
\hline 38 & 70.42 & 29.58 & 0 & 33.4 & 0.11 & 0.5 & 77 & 77.0000000001517 & $1.9 \mathrm{E}-10$ \\
\hline 39 & 68.83 & 29.21 & 1.96 & 94.2 & 0.14 & 0.5 & 96.4 & 96.4000000000049 & $6.04 \mathrm{E}-12$ \\
\hline 40 & 66.17 & 33 & 0.83 & 94.2 & 0.08 & 0.5 & 66.3 & 66.3000000000549 & $6.99 \mathrm{E}-12$ \\
\hline 41 & 64.42 & 31.96 & 3.62 & 94.2 & 0.11 & 1 & 157 & 157.000000000012 & $2.21 \mathrm{E}-11$ \\
\hline 42 & 70.42 & 29.58 & 0 & 94.2 & 0.11 & 1 & 144 & 144.000000000007 & $1.84 \mathrm{E}-11$ \\
\hline 43 & 70.18 & 29.05 & 0.77 & 94.2 & 0.2 & 0.5 & 119.9 & 119.900000000002 & $4.48 \mathrm{E}-11$ \\
\hline 44 & 65.48 & 34.52 & 0 & 94.2 & 0.11 & 0.25 & 48 & 48.000000000036 & $1.28 \mathrm{E}-9$ \\
\hline 45 & 68.88 & 29.94 & 1.18 & 66.8 & 0.11 & 0.5 & 76 & 76.0000000000458 & $1.77 \mathrm{E}-10$ \\
\hline 46 & 69.19 & 27.33 & 3.48 & 47.1 & 0.11 & 0.5 & 84 & 84.0000000001049 & $1.45 \mathrm{E}-10$ \\
\hline 47 & 69.19 & 27.33 & 3.48 & 94.2 & 0.11 & 0.25 & 55.4 & 55.4000000001085 & $4.73 \mathrm{E}-10$ \\
\hline 48 & 68.83 & 29.21 & 1.96 & 94.2 & 0.11 & 0.75 & 104.7 & 104.700000000023 & $1.65 \mathrm{E}-11$ \\
\hline
\end{tabular}


Table 5 (continued)

\begin{tabular}{|c|c|c|c|c|c|c|c|c|c|}
\hline \multirow[t]{2}{*}{ No. } & \multirow{2}{*}{$\begin{array}{l}\text { Cu content } \\
\text { (wt\%) }\end{array}$} & \multirow{2}{*}{$\begin{array}{l}\text { Zn content } \\
\text { (wt\%) }\end{array}$} & \multirow{2}{*}{$\begin{array}{l}\text { Si content } \\
\text { (wt\%) }\end{array}$} & \multirow{2}{*}{$\begin{array}{l}\text { Cutting speed } \\
\left(\mathrm{m} \mathrm{min}^{-1}\right)\end{array}$} & \multirow{2}{*}{$\begin{array}{l}\text { Feed rate } \\
\left(\mathrm{mm} \text { rev }^{-1}\right)\end{array}$} & \multirow{2}{*}{$\begin{array}{l}\text { Depth of } \\
\text { cut (mm) }\end{array}$} & \multicolumn{3}{|c|}{ Main cutting force $(\mathrm{N})$} \\
\hline & & & & & & & Measured & Predicted & Error \\
\hline 49 & 70.18 & 29.05 & 0.77 & 66.8 & 0.11 & 0.5 & 80.3 & 80.3000000000887 & $2.14 \mathrm{E}-10$ \\
\hline 50 & 68.83 & 29.21 & 1.96 & 94.2 & 0.08 & 0.5 & 71.3 & 71.3000000000914 & $5.27 \mathrm{E}-12$ \\
\hline 51 & 65.48 & 34.52 & 0 & 94.2 & 0.08 & 0.5 & 70 & 70.00000000002 & $6.61 \mathrm{E}-11$ \\
\hline 52 & 70.42 & 29.58 & 0 & 47.1 & 0.11 & 0.5 & 80.77 & 80.7700000000966 & $2.08 \mathrm{E}-12$ \\
\hline 53 & 70.42 & 29.58 & 0 & 94.2 & 0.2 & 0.5 & 114 & 114.000000000005 & $6.05 \mathrm{E}-11$ \\
\hline 54 & 64.78 & 32.94 & 2.28 & 66.8 & 0.11 & 0.5 & 65 & 65.0000000003226 & $2.7 \mathrm{E}-10$ \\
\hline 55 & 65.06 & 33.07 & 1.87 & 66.8 & 0.11 & 0.5 & 60.5 & 60.4999999997069 & $3.82 \mathrm{E}-10$ \\
\hline 56 & 65.06 & 33.07 & 1.87 & 94.2 & 0.2 & 0.5 & 93.8 & 93.8000000000328 & $4.62 \mathrm{E}-11$ \\
\hline 57 & 70.42 & 29.58 & 0 & 94.2 & 0.14 & 0.5 & 95.6 & 95.6000000000542 & $8.64 \mathrm{E}-12$ \\
\hline 58 & 64.42 & 31.96 & 3.62 & 33.4 & 0.11 & 0.5 & 77.8 & 77.8000000001305 & $5.19 \mathrm{E}-10$ \\
\hline 59 & 70.18 & 29.05 & 0.77 & 94.2 & 0.11 & 0.25 & 49.4 & 49.4000000000754 & $4.4 \mathrm{E}-11$ \\
\hline 60 & 64.78 & 32.94 & 2.28 & 94.2 & 0.08 & 0.5 & 60 & 60.0000000000892 & $6.86 \mathrm{E}-11$ \\
\hline 61 & 70.42 & 29.58 & 0 & 66.8 & 0.11 & 0.5 & 78 & 78.000000000011 & $3.78 \mathrm{E}-11$ \\
\hline 62 & 65.06 & 33.07 & 1.87 & 94.2 & 0.11 & 0.75 & 91.5 & 91.5000000000515 & $3.99 \mathrm{E}-12$ \\
\hline 63 & 70.18 & 29.05 & 0.77 & 94.2 & 0.08 & 0.5 & 72.5 & 72.5000000000011 & $2.23 \mathrm{E}-10$ \\
\hline 64 & 69.19 & 27.33 & 3.48 & 94.2 & 0.14 & 0.5 & 99 & 99.0000000000299 & $1.77 \mathrm{E}-11$ \\
\hline 65 & 70.42 & 29.58 & 0 & 94.2 & 0.11 & 0.5 & 74 & 73.9999999999584 & $5.02 \mathrm{E}-11$ \\
\hline 66 & 69.19 & 27.33 & 3.48 & 94.2 & 0.08 & 0.5 & 82 & 82.0000000000899 & $1.54 \mathrm{E}-10$ \\
\hline 67 & 65.06 & 33.07 & 1.87 & 94.2 & 0.11 & 0.25 & 40 & 40.0000000000643 & $2.03 E-10$ \\
\hline 68 & 64.42 & 31.96 & 3.62 & 94.2 & 0.2 & 0.5 & 123.9 & 123.900000000033 & $2.65 \mathrm{E}-11$ \\
\hline 69 & 65.06 & 33.07 & 1.87 & 33.4 & 0.11 & 0.5 & 62 & 62.0000000000987 & $4.68 \mathrm{E}-10$ \\
\hline
\end{tabular}

\section{Discussions}

According to the literature [26], Eq. 8 is able to predict the microstructure of Si brass cast alloy in non-equilibrium solidification condition. Since, the same casting procedure was employed in this study, ZE factor was used for investigation of the alloys microstructure. The practical data confirmed that sample 3 ( $Z E=44.3 \mathrm{wt} \%$ ) had the lowest main cutting force during 92 tests. By consideration of $Z E$ as criterion, it was confirmed that the proposed alloy by ANN-COA-GA model had nearly the same ZE value (44.3 wt $\%<Z E<46.2$ wt $\%)$.

It was necessary to note that the Si brass alloys with above-mentioned ZE encouraged the formation of Widmanstätten morphologies. The presence of this type of microstructure could result in the strength differences at interphase boundaries [29] enhancing the fracturing during the machining. This brittle fracture behavior was intensified by the presence of strong anisotropy at the interface of the Widmanstäetten and matrix phases [30].

Obviously, $a$ and $\beta^{\prime}$ phases have various plastic deformation behavior and consequently during the applying of dynamic force by the tool tip, the interface of $a$ and $\beta^{\prime}$ acts as appropriate sites for the nucleation and growth of the voids. Connection of these voids facilitates the formation of microcracks and brittle fracture during the dynamic loading. The observation of peak shifts for $a$ and $\beta^{\prime}$ phases in chip of the sample 3 in Fig. 13 is the evidence for the presence of a large amounts of strains aiding the easy fracturing. Moreover, the formation of finer grain in 
Table 6 Experimental data and predicted output from the ANN-COA network for testing set

\begin{tabular}{|c|c|c|c|c|c|c|c|c|c|}
\hline \multirow[t]{2}{*}{ No. } & \multirow{2}{*}{$\begin{array}{l}\text { Cu content } \\
\text { (wt\%) }\end{array}$} & \multirow{2}{*}{$\begin{array}{l}\text { Zn content } \\
\text { (wt\%) }\end{array}$} & \multirow{2}{*}{$\begin{array}{l}\text { Si content } \\
\text { (wt\%) }\end{array}$} & \multirow{2}{*}{$\begin{array}{l}\text { Cutting speed } \\
\left(\mathrm{m} \mathrm{min}^{-1}\right)\end{array}$} & \multirow{2}{*}{$\begin{array}{l}\text { Feed rate } \\
\left(\mathrm{mm} \mathrm{rev}{ }^{-1}\right)\end{array}$} & \multirow{2}{*}{$\begin{array}{l}\text { Depth of } \\
\text { cut }(\mathrm{mm})\end{array}$} & \multicolumn{3}{|c|}{ Main cutting force $(\mathrm{N})$} \\
\hline & & & & & & & Measured & Predicted & Error \\
\hline 1 & 64.42 & 31.96 & 3.62 & 94.2 & 0.11 & 0.25 & 58 & 58.0000000001572 & $3.4 \mathrm{E}-8$ \\
\hline 2 & 66.17 & 33 & 0.83 & 94.2 & 0.14 & 0.5 & 92.5 & 92.5000000000088 & $1.2 \mathrm{E}-8$ \\
\hline 3 & 68.88 & 29.94 & 1.18 & 94.2 & 0.11 & 0.75 & 109.8 & 109.800000000009 & $2.6 \mathrm{E}-8$ \\
\hline 4 & 65.48 & 34.52 & 0 & 33.4 & 0.11 & 0.5 & 99 & 99.0000000000413 & $2.3 \mathrm{E}-8$ \\
\hline 5 & 64.78 & 32.94 & 2.28 & 94.2 & 0.11 & 1 & 129 & 128.999999999997 & $6.9 \mathrm{E}-10$ \\
\hline 6 & 68.83 & 29.21 & 1.96 & 94.2 & 0.11 & 0.25 & 48.3 & 48.3000000000619 & $4.9 \mathrm{E}-9$ \\
\hline 7 & 68.88 & 29.94 & 1.18 & 94.2 & 0.2 & 0.5 & 111.5 & 111.500000000007 & $3.5 \mathrm{E}-8$ \\
\hline 8 & 65.06 & 33.07 & 1.87 & 94.2 & 0.08 & 0.5 & 57 & 56.9999999999461 & $3.9 \mathrm{E}-10$ \\
\hline 9 & 70.18 & 29.05 & 0.77 & 94.2 & 0.11 & 0.75 & 111 & 110.999999999983 & $5.5 \mathrm{E}-8$ \\
\hline 10 & 65.48 & 34.52 & 0 & 47.1 & 0.11 & 0.5 & 94 & 94.0000000000418 & $1.3 \mathrm{E}-8$ \\
\hline 11 & 65.48 & 34.52 & 0 & 94.2 & 0.11 & 0.5 & 87 & 87.0000000000152 & $4.5 \mathrm{E}-9$ \\
\hline 12 & 66.17 & 33 & 0.83 & 94.2 & 0.11 & 0.75 & 108 & 108.0000000014 & $1.3 \mathrm{E}-9$ \\
\hline 13 & 69.19 & 27.33 & 3.48 & 66.8 & 0.11 & 0.5 & 80 & 80.000000000052 & $7.9 \mathrm{E}-9$ \\
\hline 14 & 68.83 & 29.21 & 1.96 & 33.4 & 0.11 & 0.5 & 67.5 & 67.5000000001224 & $2 \mathrm{E}-8$ \\
\hline 15 & 65.06 & 33.07 & 1.87 & 94.2 & 0.14 & 0.5 & 79 & 79.0000000001808 & $2.1 \mathrm{E}-8$ \\
\hline 16 & 64.42 & 31.96 & 3.62 & 66.8 & 0.11 & 0.5 & 92.2 & 92.2000000000748 & $1.2 \mathrm{E}-9$ \\
\hline 17 & 66.17 & 33 & 0.83 & 94.2 & 0.11 & 0.5 & 81.5 & 81.5000000000145 & $1.1 \mathrm{E}-8$ \\
\hline 18 & 65.48 & 34.52 & 0 & 94.2 & 0.11 & 0.75 & 110 & 110.000000000006 & $5.1 \mathrm{E}-9$ \\
\hline 19 & 68.88 & 29.94 & 1.18 & 47.1 & 0.11 & 0.5 & 82 & 82.0000000000681 & $3 E-8$ \\
\hline 20 & 65.06 & 33.07 & 1.87 & 47.1 & 0.11 & 0.5 & 63 & 63.0000000001787 & $2.1 \mathrm{E}-8$ \\
\hline 21 & 70.18 & 29.05 & 0.77 & 33.4 & 0.11 & 0.5 & 94.6 & 94.600000000142 & $6.1 \mathrm{E}-9$ \\
\hline 22 & 66.17 & 33 & 0.83 & 33.4 & 0.11 & 0.5 & 74.5 & 74.5000000001205 & $2 \mathrm{E}-8$ \\
\hline 23 & 66.17 & 33 & 0.83 & 66.8 & 0.11 & 0.5 & 82 & 82.0000000000921 & $1.3 \mathrm{E}-8$ \\
\hline
\end{tabular}

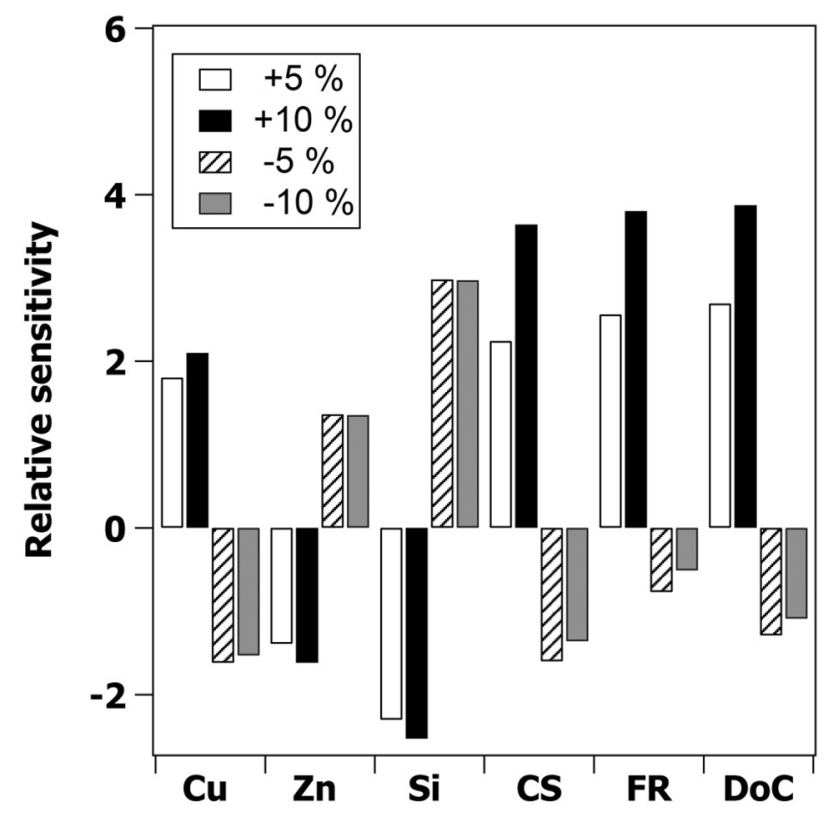

the presence of higher Si content (Fig. 10), enhanced the interface of the phases and intensified the brittle fracture.

By consideration of the effect of operational parameters on the main cutting force revealed that, at higher FR and DoC, more volume of the work piece material could be removed during the cutting operation causing more resistance against tool which led to the direct relation of these parameters with the main cutting force in sensitivity analysis.

The relatively high sensitivity observed in Fig. 7 for the main cutting force with cutting speed variations was due to the competition between the work hardening and thermal softening phenomena during machining. By increasing in cutting speeds, high strain rates create during the chip formation resulting in work hardening in work piece material. By passing the strain rate from a threshold, the high heat generation which is produced by severe plastic deformation leads to a localized increase in temperature. Consequently, drop in shear strength occurs which is known as thermal softening. It has been observed in austenitic stainless steels [31], Ti-6Cr-5Mo-5V-4Al [32]

Fig. 7 The sensitivity analysis of the input variables on the main cutting force using ANN-COA model 

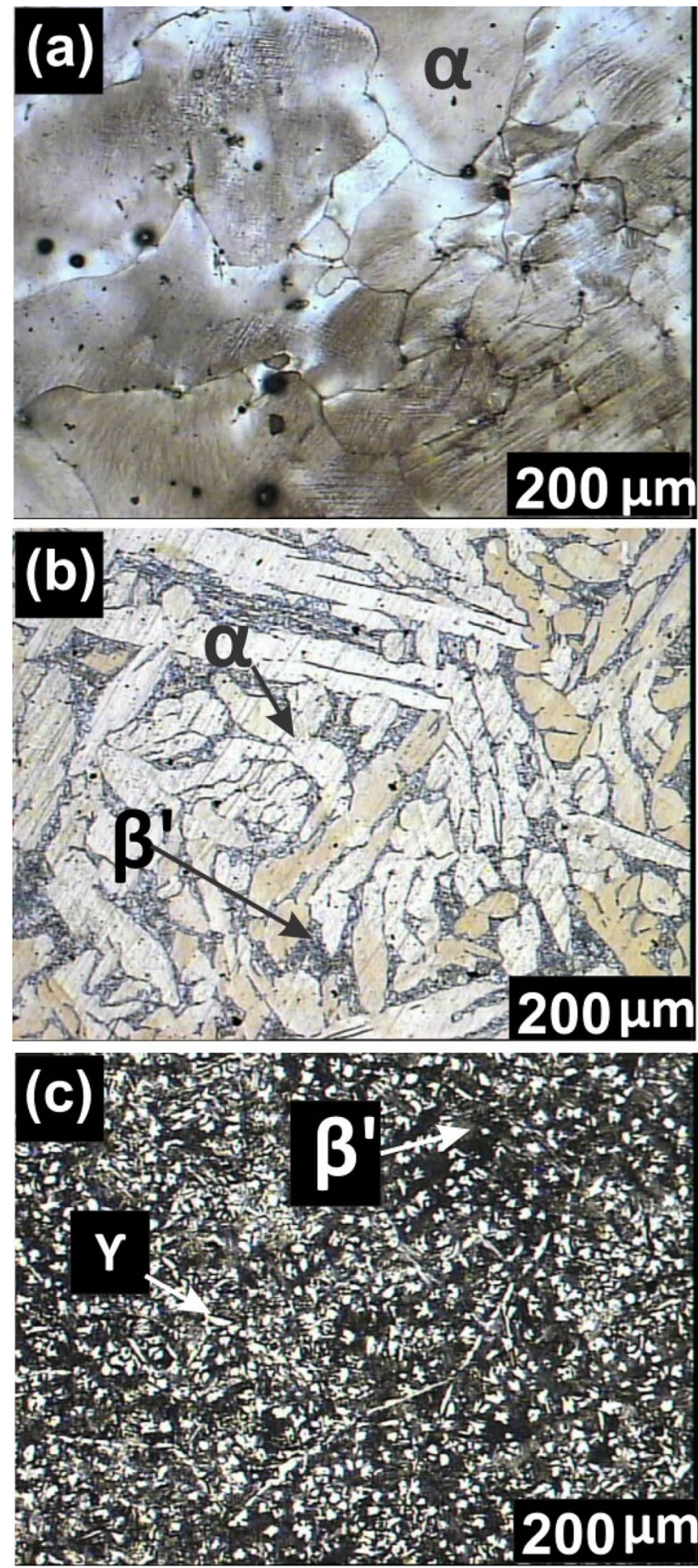

Fig. 8 Typically microstructure of the Si brass alloys a sample 6 with 0 wt $\%$ Si b sample 9 with 1.96 wt $\%$ Si (the lighter phase is a) c sample 10 with 3.48 wt $\%$ Si (the lighter phase is ) and $\mathrm{Al}-(1-2) \mathrm{Fe}-1 \mathrm{~V}-1 \mathrm{Si}$ [33] alloys that the critical strain hardening is the inherent characteristics for each material.

Most of the Si containing samples in this study showed work hardening with cutting speeds variation at the range of 33.4-94.2 $\mathrm{m} \mathrm{min}^{-1}$. Lack of the observation of work hardening for samples 3 and 4 was due to the ability of these samples to be fractured without the significant plastic deformation due to the presence of the Widmanstäetten morphologies [8].

\section{Conclusions}

In this study, the main cutting forces of different as-cast $\mathrm{Si}$ brass alloys were measured at various operating parameters including cutting speed, feed rate and depth of cut. It has been shown that the ANN-COA is an efficient approach for modeling and optimization of the main cutting force. The following main results were acquired.

1. The ANN network with 6-10-7-1 structure using tansig function for hidden layers and pureline for output layer had the best prediction ability. The regression and MAPE amounts for this network were 0.9307 and $9.025 \%$, respectively.

2. The usage of COA for optimizing the weight and bias achieved by ANN model improved the accuracy of the proposed network by ANN.

3. The $Z E$ factor was utilized for sorting Si brass alloys with the minimum amounts of main cutting force. The alloy with ZE value of $44.97 \mathrm{wt} \%$ was predicted by GA algorithm as candidate for the lowest main cutting force during the machining process.

4. By consideration of $Z E$ as criterion, proposed that $Z E$ between 44.3 and $46.2 \mathrm{wt} \%$ provided the possibility of the formation of $a$ Widmanstätten phase and promotion of the machinability through a weakness at interface between Widmanstätten morphologies and matrix phase.

For future works, the hybrid ANN-COA technique may use for modeling and optimization of the main cutting force in other ternary brass systems alloyed with different alloying elements in order to evaluate the capability of this approach as well as the ZE criterion to predict the machining behavior of brasses. 

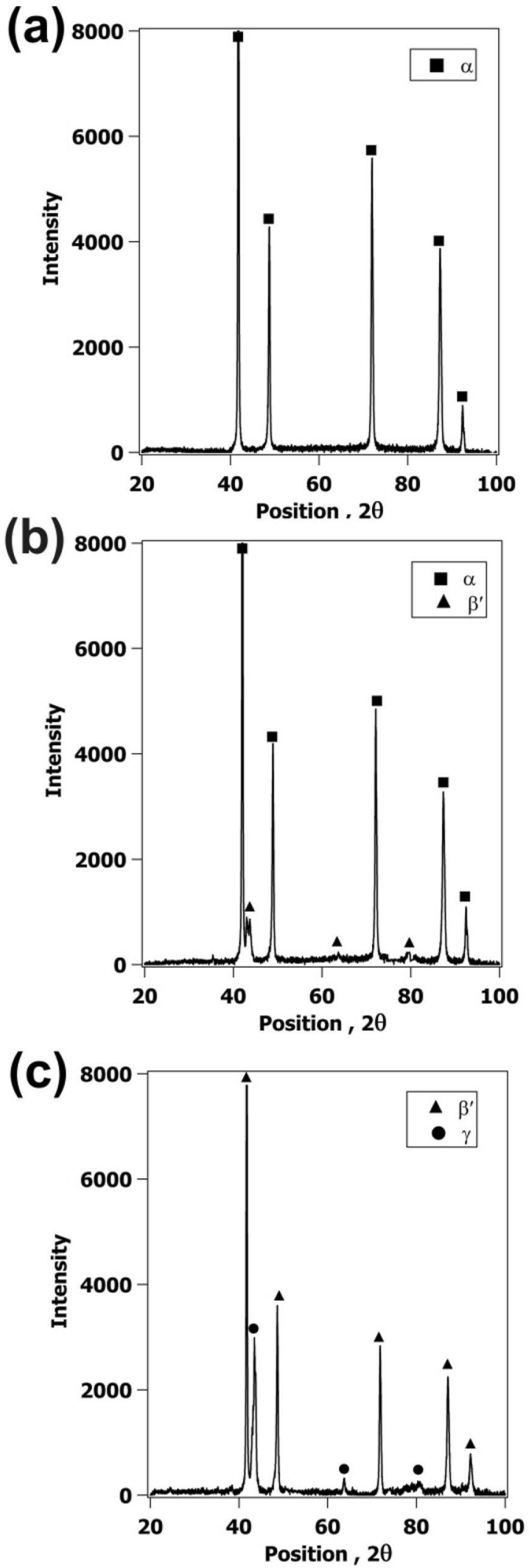

Fig. 9 The XRD patterns of the Si brass alloys a sample 6 with 0 wt $\%$ Si b sample 9 with 1.96 wt $\%$ Si c sample 10 with 3.48 wt\% Si

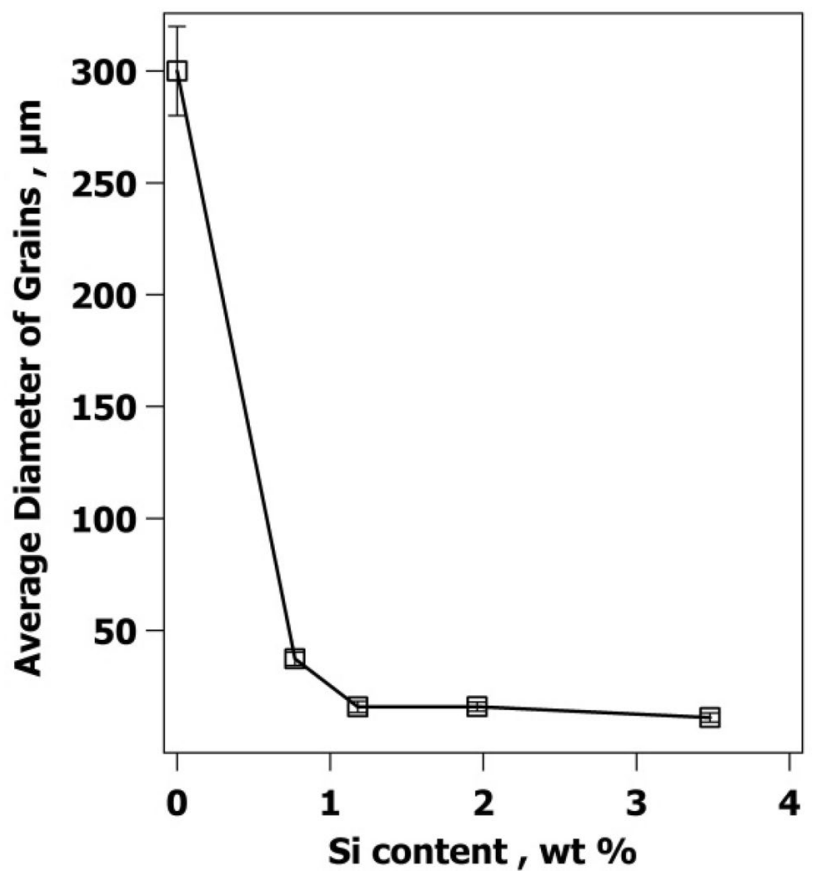

Fig. 10 The ADG diagram of $\mathrm{Cu}_{70}-\mathrm{Zn}_{30}$ base alloy as a function of Si content

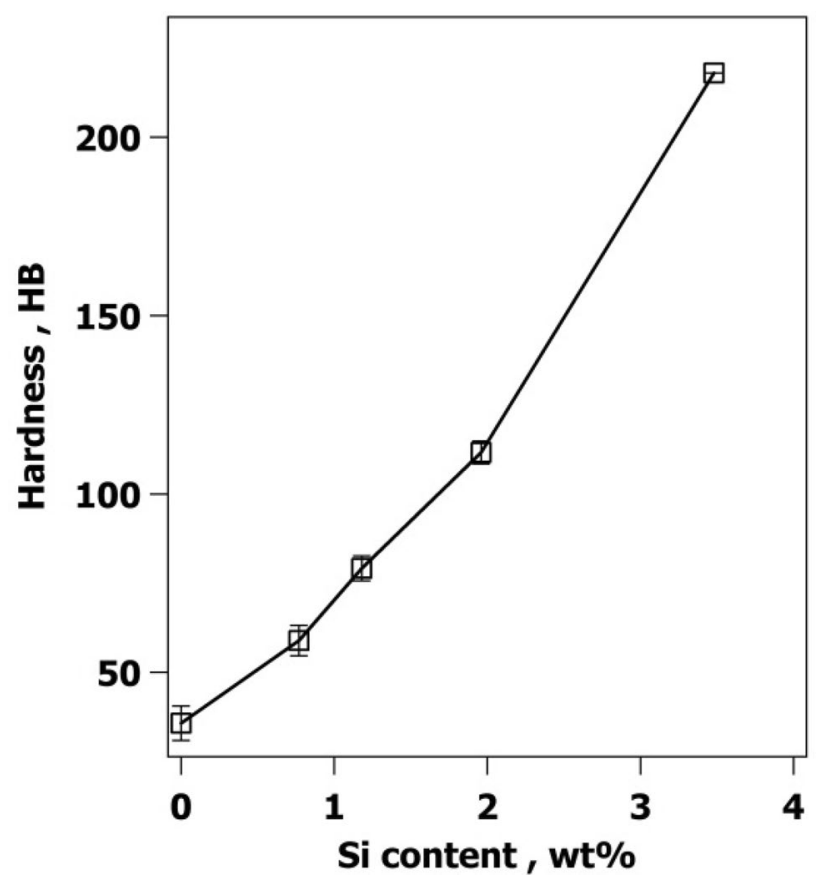

Fig. 11 The hardness diagram of $\mathrm{Cu}_{70}-\mathrm{Zn}_{30}$ base alloy as a function of Si content 
Table 7 Results of ANN-COA-GA program and experimental validations

\begin{tabular}{|c|c|c|c|c|c|c|c|c|c|}
\hline \multirow[t]{2}{*}{ No. } & \multirow{2}{*}{$\begin{array}{l}\text { Cu content } \\
\text { (wt\%) }\end{array}$} & \multirow{2}{*}{$\begin{array}{l}\text { Zn content } \\
\text { (wt\%) }\end{array}$} & \multirow{2}{*}{$\begin{array}{l}\text { Si content } \\
\text { (wt\%) }\end{array}$} & \multirow{2}{*}{$\begin{array}{l}\text { Cutting speed } \\
\left(\mathrm{m} \mathrm{min}^{-1}\right)\end{array}$} & \multirow{2}{*}{$\begin{array}{l}\text { Feed rate } \\
\left(\mathrm{mm} \mathrm{rev}^{-1}\right)\end{array}$} & \multirow{2}{*}{$\begin{array}{l}\text { Depth of } \\
\text { cut }(\mathrm{mm})\end{array}$} & \multicolumn{3}{|c|}{ Main cutting force $(\mathrm{N})$} \\
\hline & & & & & & & Measured & Predicted & Error \\
\hline 1 & 65.48 & 34.52 & 0 & 94.2 & 0.11 & 1 & 140.8 & 140.799999966242 & $2.39 \mathrm{E}-10$ \\
\hline 2 & 66.17 & 33 & 0.83 & 94.2 & 0.11 & 1 & 134 & 134.000000038759 & $2.89 \mathrm{E}-10$ \\
\hline 3 & 65.06 & 33.07 & 1.87 & 94.2 & 0.11 & 1 & 122 & 122.000000046247 & $3.79 \mathrm{E}-10$ \\
\hline 4 & 64.78 & 32.94 & 2.28 & 33.4 & 0.11 & 0.5 & 68 & 67.9999999337485 & $9.74 \mathrm{E}-10$ \\
\hline 5 & 70.18 & 29.05 & 0.77 & 94.2 & 0.11 & 1 & 147 & 147.000000055006 & $3.74 \mathrm{E}-10$ \\
\hline 6 & 68.88 & 29.94 & 1.18 & 33.4 & 0.11 & 0.5 & 84 & 84.0000000212458 & $2.53 \mathrm{E}-10$ \\
\hline 7 & 68.83 & 29.21 & 1.96 & 94.2 & 0.11 & 1 & 131 & 130.999999967488 & $2.48 \mathrm{E}-10$ \\
\hline 8 & 69.19 & 27.33 & 3.48 & 33.4 & 0.11 & 0.5 & 70.4 & 70.4000000200009 & $2.84 \mathrm{E}-10$ \\
\hline
\end{tabular}

Fig. 12 Typically optical micrographs of a sample 3 with ZE of $44.3 \mathrm{wt} \%$ containing a Widmanstäetten plates $\mathbf{b}$ sample 4 with ZE of 46.2 wt $\%$ containing a Widmanstäetten needles along the grain boundaries $\mathbf{c}$ high magnification of (b)
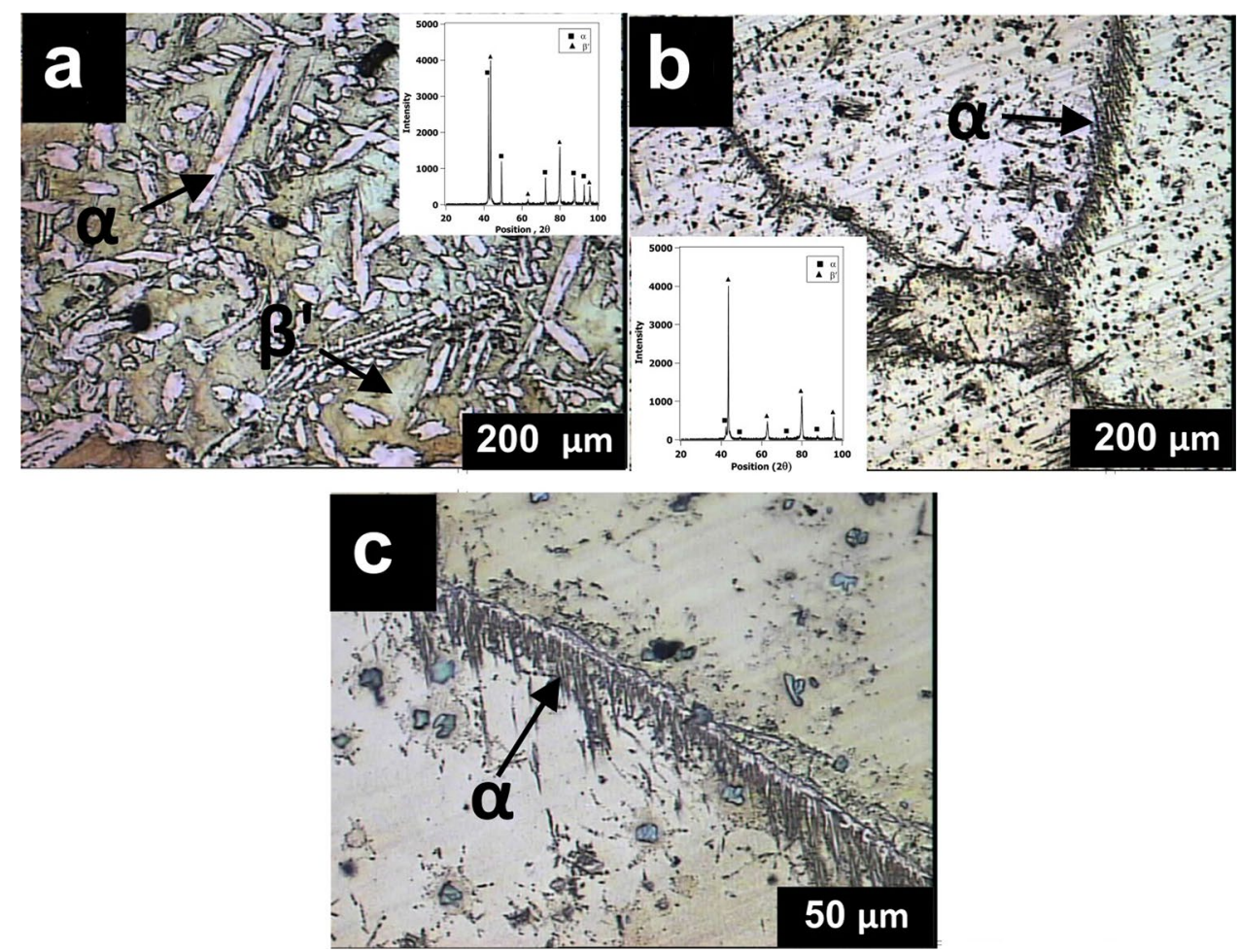

SN Applied Sciences 


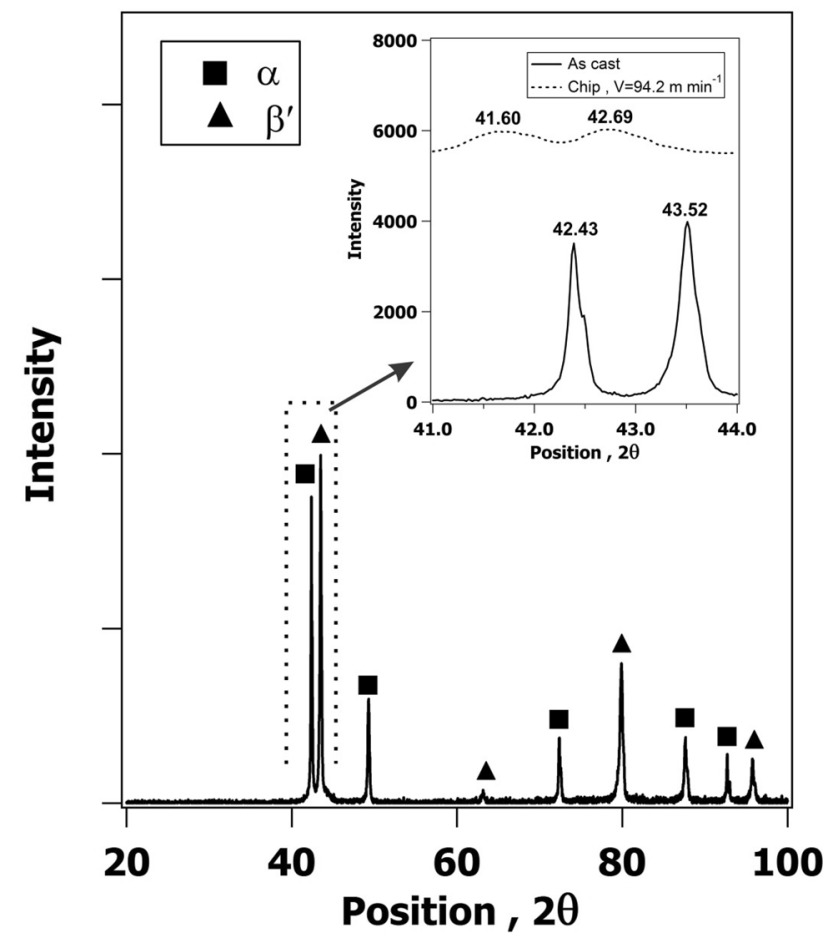

Fig. 13 The XRD patterns comparison of sample 3 in as cast and chip $\left(C S=94.2 \mathrm{~m} \mathrm{~min}^{-1}, \mathrm{FR}=0.11 \mathrm{~mm} \mathrm{rev}^{-1}\right.$ and $\left.\mathrm{DoC}=1 \mathrm{~mm}\right)$ forms

Acknowledgement Authors are thankful to Dr Gholam Reza Khayati for his valuable comments and discussion during the writing of this paper.

\section{Compliance with ethical standards}

Conflict of interest The authors declare that they have no conflict of interest.

Open Access This article is licensed under a Creative Commons Attribution 4.0 International License, which permits use, sharing, adaptation, distribution and reproduction in any medium or format, as long as you give appropriate credit to the original author(s) and the source, provide a link to the Creative Commons licence, and indicate if changes were made. The images or other third party material in this article are included in the article's Creative Commons licence, unless indicated otherwise in a credit line to the material. If material is not included in the article's Creative Commons licence and your intended use is not permitted by statutory regulation or exceeds the permitted use, you will need to obtain permission directly from the copyright holder. To view a copy of this licence, visit http://creativecommons .org/licenses/by/4.0/.

\section{References}

1. Bushlya V, Johansson D, Lenrick F, Ståhl JE, Schultheiss F (2017) Wear mechanisms of uncoated and coated cemented carbide tools in machining lead-free silicon brass. Wear 376:143-151. https://doi.org/10.1016/j.wear.2017.01.039
2. Toulfatzis Al, Pantazopoulos GA, Paipetis AS (2016) Microstructure and properties of lead-free brasses using post-processing heat treatment cycles. Mater Sci Technol 32(17):1771-1781. https://doi.org/10.1080/02670836.2016.1221493

3. Schultheiss F, Johansson D, Bushlya V, Zhou J, Nilsson K, Ståhl JE (2017) Comparative study on the machinability of lead-free brass. J Clean Prod 149:366-377. https://doi.org/10.1016/j.jclep ro.2017.02.098

4. Vilarinho C, Davim JP, Soares D, Castro F, Barbosa J (2005) Influence of the chemical composition on the machinability of brasses. J Mater Process Technol 170(1-2):441-447. https://doi. org/10.1016/j.jmatprotec.2005.05.035

5. Nobel C, Klocke F, Lung D, Wolf S (2014) Machinability enhancement of lead-free brass alloys. Procedia CIRP 14:95-100. https:// doi.org/10.1016/j.procir.2014.03.018

6. Lü YZ, Wang QD, Zeng XQ, Ding WJ, Zhu YP (2001) Effects of silicon on microstructure, fluidity, mechanical properties, and fracture behaviour of Mg-6Al alloy. Mater Sci Technol 17(2):207214. https://doi.org/10.1179/026708301101509872

7. Oishi K (2002) U.S. Patent No. 6,413,330. U.S. Patent and Trademark Office, Washington, DC

8. Adineh M, Doostmohammadi $H$, Raiszadeh R (2019) Effect of $\mathrm{Si}$ and $\mathrm{Al}$ on the microstructure, mechanical properties and machinability of 65Cu-35Zn Brass. IJMSE 16(2):21-32

9. Karunakar DB, Datta GL (2008) Prevention of defects in castings using back propagation neural networks. Int J Adv Manuf Technol 39(11-12):1111-1124. https://doi.org/10.1007/s0017 0-007-1289-0

10. Anijdan SM, Madaah-Hosseini HR, Bahrami A (2007) Flow stress optimization for 304 stainless steel under cold and warm compression by artificial neural network and genetic algorithm. Mater Des 28(2):609-615. https://doi.org/10.1016/j.matde s.2005.07.018

11. Pepe G, Looney L, Hashmi MSJ, Galantucci LM (1999) Predicting the wear resistance of WC-Co coatings using neural networks. Int J Model Simul 19(4):410-417. https://doi.org/10.1080/02286 203.1999.11760272

12. Jafari MM, Khayati GR (2016) Artificial neural network based prediction hardness of Al2024-Multiwall carbon nanotube composite prepared by mechanical alloying. IJE Trans C 29(12):1726-1733

13. Varol T, Canakci A, Ozsahin S (2017) Prediction of effect of reinforcement content, flake size and flake time on the density and hardness of flake AA2024-SiC nanocomposites using neural networks. J Alloys Compd 739:1005-1014. https://doi. org/10.1016/j.jallcom.2017.12.256

14. Manjunath Patel GC, Krishna P, Parappagoudar MB (2016) An intelligent system for squeeze casting process—soft computing based approach. Int J Adv Manuf Technol 86(9-12):3051-3065. https://doi.org/10.1007/s00170-016-8416-8

15. He F, Zhang L (2018) Mold breakout prediction in slab continuous casting based on combined method of GA-BP neural network and logic rules. Int J Adv Manuf Technol 95(9-12):40814089. https://doi.org/10.1007/s00170-017-1517-1

16. Arafat M, Sjafrizal T, Anugraha RA (2020) An artificial neural network approach to predict energy consumption and surface roughness of a natural material. SN Appl Sci 2:1-11. https://doi. org/10.1007/s42452-020-2987-6

17. Jafari S, Bozorg-Haddad O, Chu X (2018) Cuckoo optimization algorithm (COA). In: Bozorg-Haddad O (ed) Advanced optimization by nature-inspired algorithms. Studies in computational intelligence, vol 720. Springer, Berlin, pp 39-49. https://doi. org/10.1007/978-981-10-5221-7_5

18. Joshi AS, Kulkarni O, Kakandikar GM, Nandedkar VM (2017) Cuckoo search optimization: a review. Mater Today Proc 4(8):7262-7269. https://doi.org/10.1016/j.matpr.2017.07.055 
19. Sohrabpoor H, Khanghah SP, Shahraki S, Teimouri R (2016) Multi-objective optimization of electrochemical machining process. Int J Adv Manuf Technol 82(9-12):1683-1692. https:// doi.org/10.1007/s00170-015-7448-9

20. Moezi SA, Zakeri E, Zare A (2017) A generally modified cuckoo optimization algorithm for crack detection in cantilever Euler-Bernoulli beams. Precis Eng 52:227-241. https://doi. org/10.1016/j.precisioneng.2017.12.010

21. Teimouri R, Sohrabpoor H (2013) Application of adaptive neurofuzzy inference system and cuckoo optimization algorithm for analyzing electro chemical machining process. Front Mech Eng 8(4):429-442. https://doi.org/10.1007/s11465-013-0277-3

22. Mellal MA, Williams EJ (2016) Total production time minimization of a multi-pass milling process via cuckoo optimization algorithm. Int J Adv Manuf Technol 87(1-4):747-754. https:// doi.org/10.1007/s00170-016-8498-3

23. Mahdavi Jafari M, Khayati GR, Hosseini M, Danesh-Manesh H (2017) Modeling and optimization of roll-bonding parameters for bond strength of $\mathrm{Ti} / \mathrm{Cu} / \mathrm{Ti}$ clad composites by artificial neural networks and genetic algorithm. IJE Trans B Asp 30(12):1885-1893

24. Rajabi Z, Doostmohammadi $\mathrm{H}$ (2018) Effect of addition of tin on the microstructure and machinability of a-brass. Mater Sci Technol. https://doi.org/10.1080/02670836.2018.1435484

25. Adineh $M$, Doostmohammadi H (2019) Microstructure, mechanical properties and machinability of $\mathrm{Cu}-\mathrm{Zn}-\mathrm{Mg}$ and $\mathrm{Cu}-\mathrm{Zn}-\mathrm{Sb}$ brass alloys. Mater Sci Technol 35(12):1504-1514. https://doi. org/10.1080/02670836.2019.1630089

26. Alirezaei M, Doostmohammadi H (2016) Microstructure evolution in cast and equilibrium heat-treated CuZn30-(Si) alloys. Int J Cast Met Res 29(4):222-227. https://doi.org/10.1080/13640 461.2015.1126430
27. Gale WF, Totemeier TC (2003) Smithells metals reference book. Elsevier, Amsterdam

28. Velásquez JP, Bolle B, Chevrier P, Geandier G, Tidu A (2007) Metallurgical study on chips obtained by high speed machining of a Ti-6 wt\% Al-4 wt\% V alloy. Mater Sci Eng A 452:469-474. https ://doi.org/10.1016/j.msea.2006.10.090

29. Gil FJ, Ginebra MP, Manero JM, Planell JA (2001) Formation of a-Widmanstätten structure: effects of grain size and cooling rate on the Widmanstätten morphologies and on the mechanical properties in Ti6Al4V alloy. J Alloys Compd 329(1-2):142-152. https://doi.org/10.1016/S0925-8388(01)01571-7

30. Loginova I, Ågren J, Amberg G (2004) On the formation of Widmanstätten ferrite in binary $\mathrm{Fe}-\mathrm{C}$-phase-field approach. Acta Mater 52(13):4055-4063. https://doi.org/10.1016/j.actam at.2004.05.033

31. Fernández-Abia Al, García JB, de Lacalle LNL (2013) High-performance machining of austenitic stainless steels. In: Machining and machine-tools, pp 29-90. https://doi.org/10.1533/97808 57092199.29

32. Rashid RR, Sun S, Wang G, Dargusch MS (2012) An investigation of cutting forces and cutting temperatures during laser-assisted machining of the $\mathrm{Ti}-6 \mathrm{Cr}-5 \mathrm{Mo}-5 \mathrm{~V}-4 \mathrm{Al}$ beta titanium alloy. Int J Mach Tools Manuf 63:58-69. https://doi.org/10.1016/j.ijmac htools.2012.06.004

33. Pathak BN, Sahoo KL, Mishra M (2013) Effect of machining parameters on cutting forces and surface roughness in $\mathrm{Al}-(1-2)$ Fe-1V-1Si alloys. Mater Manuf Processes 28(4):463-469. https ://doi.org/10.1080/10426914.2013.763952

Publisher's Note Springer Nature remains neutral with regard to jurisdictional claims in published maps and institutional affiliations. 